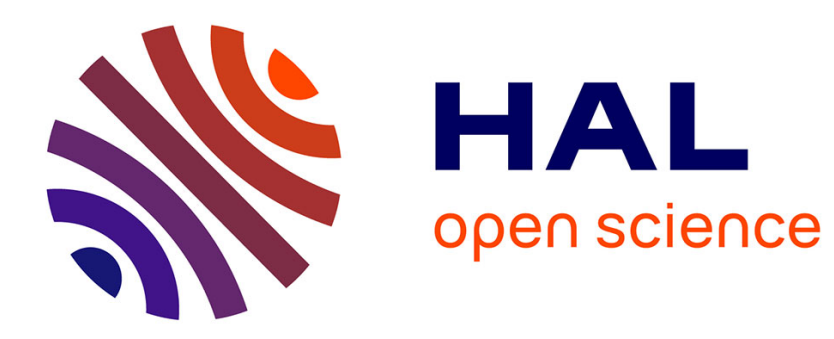

\title{
Three extreme cases of neutralisation: nasality, retroflexion and lip-rounding in Naxi
}

\author{
Alexis Michaud
}

\section{To cite this version:}

Alexis Michaud. Three extreme cases of neutralisation: nasality, retroflexion and lip-rounding in Naxi.

Cahiers de linguistique - Asie Orientale, 2006, 35(1), pp. 23-55. hal-00130120

\author{
HAL Id: hal-00130120 \\ https://hal.science/hal-00130120
}

Submitted on 9 Feb 2007

HAL is a multi-disciplinary open access archive for the deposit and dissemination of scientific research documents, whether they are published or not. The documents may come from teaching and research institutions in France or abroad, or from public or private research centers.
L'archive ouverte pluridisciplinaire HAL, est destinée au dépôt et à la diffusion de documents scientifiques de niveau recherche, publiés ou non, émanant des établissements d'enseignement et de recherche français ou étrangers, des laboratoires publics ou privés. 
Reference Type: Journal Article

Record Number: 1073

Author: Michaud, Alexis

Year: 2006

Title: Three extreme cases of neutralisation: nasality, retroflexion and lip-rounding in Naxi

Journal: Cahiers de linguistique - Asie Orientale

Volume: 35

Issue: 1

Pages: 23-55

PREPRINT VERSION 


\section{Preprint version \\ of paper \\ published in: \\ Cahiers de \\ Linguistique Asie \\ Orientale 35:1 \\ (2006).}

\section{Three extreme cases of neutralisation: nasality, retroflexion and lip-rounding in Naxi}

Abstract: New data on dialects of Naxi (a Sino-Tibetan language) allow for some progress in the analysis of their phonemic system. The present analyses bear on three contrasts: (i) between oral rhymes $/ \mathrm{i} /, / \mathrm{y} /$ and $/ \mathrm{v} /$ and nasal $/ \tilde{\mathrm{i}} /, / \tilde{\mathrm{y}} /$ and $/ \tilde{\mathrm{v}} /$ a contrast which is present in a single dialect, and which partly subsists as a contrast of initial fricatives $/ \mathrm{h} /$ and $/ \mathrm{c} /$ in another dialect; (ii) between retroflex and non-retroflex coronal initials; and (iii) between syllables with and without liprounding $(/ \mathrm{w} /)$ after a coronal initial. From a strictly synchronic point of view, these phenomena constitute extreme instances of neutralisation; from a diachronic point of view, their analysis provides some landmarks for reconstruction.

Keywords: Naxi; phonemics; nasal; retroflex; labialisation; neutralisation.

\section{Trois cas extrêmes de neutralisation :} nasalité, rétroflexion et arrondissement labial en naxi

Résumé : Des données nouvelles sur les dialectes du naxi (langue sino-tibétaine) permettent certaines avancées dans l'analyse de leur système phonémique. Les présentes analyses portent sur trois oppositions : 1) entre rimes orales $/ \mathrm{i} /, / \mathrm{y} /, / \mathrm{y} /$ et nasales $/ \tilde{1} /, / \tilde{y} /, / \tilde{y} /$, opposition présente dans un seul dialecte, en partie préservée, dans un autre dialecte, sous la forme d'une opposition entre fricatives initiales $/ \mathrm{h} /$ et $/$ ç/ ;2) entre initiales coronales rétroflexes et non rétroflexes ; 3) entre syllabes avec et sans labialisation $(/ \mathrm{w} /)$ après une initiale coronale. Sur un plan strictement synchronique, ces phénomènes représentent des cas extrêmes de neutralisation; au plan diachronique, leur analyse revient à poser quelques jalons en vue d'un travail de reconstruction.

Mots-clefs : naxi ; phonématique ; nasal ; rétroflexe ; labialisation ; neutralisation.

Alexis Michaud, Laboratoire de Phonétique et Phonologie, UMR 7018 CNRS-Sorbonne Nouvelle, alexis.michaud@univ-paris3.fr 


\section{Introduction}

Naxi is a Sino-Tibetan language spoken by some 300,000 people mostly concentrated in the Gucheng District (lìjiāng gŭ chéng qū 丽江古城区) and the Yulong Naxi autonomous county (yù lóng nà xī zú zì zhì xiàn 玉龙纳西族自治县) which, together, formerly made up the Lijiang Naxi Autonomous County (lì jiāng nàxī zú zì zhì xiàn 丽江纳西族自治县) of the province of Yunnan, China. The Chinese name of the language is nà xīyŭ 纳西语; the autonym in the Western dialects is /nd $\mathrm{hi}^{-} \%$. It is close to, though not a member of, the Burmese-Yi branch of Sino-Tibetan (Bradley 1975, 1979, 1997:37; Matisoff 2003:5, 8; Thurgood 2003:20). The syllabic structure of Naxi is strikingly different from that of ProtoTibeto-Burman as reconstructed by Paul Benedict (1972) and James Matisoff (2003). Like the Yi languages (彝语 yí yǔ in Chinese; formerly known as Lolo $^{1}$ ), Naxi is a monosyllabic language without final consonants or consonant clusters. Most syllables are simply made up of a consonant and a vowel; syllabic structure is $(\mathrm{C})(\mathrm{G}) \mathrm{V}$, where $\mathrm{C}$ is a consonant, $\mathrm{G}$ a semi-vowel /w/ or $/ \mathrm{j} /$ (with a severely restricted distribution), and $\mathrm{V}$ a vowel; brackets indicate optional constituents. $^{2}$

Naxi is nonetheless a language of some phonemic complexity. The present analyses bear mainly on the dialect of the village of /ā sə̀),

\footnotetext{
${ }^{1}$ David Bradley proposed the designation $\mathrm{Ni}$ for the languages formerly called $\mathrm{Yi}$ or Lolo (Bradley 1995:1, note 2). Ni is a relatively common autonym among the languages concerned (e.g. Hani, Sani...), whereas $Y i$ and Lolo are exonyms, the second being moreover derogatory. Quite recently, Bradley proposed a new improvement over this designation, changing it to Ngwi in light of advances in the reconstruction of 'Proto-Yi'. The compromise choice made here is to retain the widespread designation $Y i$.

${ }^{2}$ For an inventory of Naxi syllables, and a glimpse of Naxi studies, see, in the present issue, "Syllabic inventory of a Naxi dialect, and correspondence with Joseph Rock's transcriptions".
} 
hamlet of /lé p⿳亠丷厂 lò/ (in Chinese: lì jiāng gŭ chéng qū, wén huà xíng zhèng cūn, lěng bù luó zì rán cūn 丽江古城区, 文化行政村, 冷不罗自然村), abbreviated as AS, and, to a lesser extent, on the dialect of the village of /fỵ́ $\mathrm{k}^{\mathrm{h}} \overline{\mathrm{o}} /$ (in Chinese: yù lóng nà xī zú zì zhì xiàn, fèng kē xiāng, shàn měi xíng zhèng cūn, héng kě èr zǔ 玉龙纳西族自治县，奉科乡，善美行政村，恒可二组), abbreviated as FK. Some data from the village of /ndā lè/ (abbreviated to NL) will be adduced in the course of the discussion (the Chinese coordinates of the NL dialect are: lìjiāng gǔ chéng qū, guì fēng dà lái xíng zhèng xià cūn 丽江古城区, 贵峰大来行政下村/大来二村). These dialects were investigated first-hand in 2002 and 2004. The map which accompanies this paper shows these locations, as well as the town of Lijiang, whose dialect is abbreviated to DYZ, for Dàyánzhèn (大研镇), which designates the historical city centre.

The three contrasts studied here are:

1) the contrast between oral rhymes $/ \mathrm{i} /, / \mathrm{y} /$ and $/ \mathrm{v} /$, on the one hand, and nasal rhymes $/ \tilde{1} /, / \tilde{y} /$ and $/ \tilde{v} /$ on the other. This contrast is found in only one of the dialects investigated (this dialect is referred to as FK; see below, section 1.2), and only after initial $/ \mathrm{h} /$. In the AS dialect (see, again, section 1.2), which does not possess nasal vowels, the distinction between the lexical items that have rhymes $/ \mathrm{i} /: / \tilde{\mathrm{i}} /$ or $/ \mathrm{v} /: / \tilde{\mathrm{v}} /$ in FK is lost altogether, whereas the distinction between the $/ y /$ and $/ \tilde{y} /$ of $F K$ subsists on the initial consonant of the syllables at issue: /ç/ vs. /h/;

2) the contrast between retroflex and non-retroflex coronal initials before vowel /o/ in the AS dialect;

3 ) the contrast between syllables with and without labialisation $(/ \mathrm{w} /)$ between a coronal initial and the rhotic vowel $/ x /$ (and only this vowel), again in the AS dialect. 
Map showing part of the

Yulong Naxi Autonomous County 纳 and of the Lijiang Gucheng

District (which, together,

formerly made up the Lijiang

Naxi Autonomous County),

indicating the position

of the main dialects

referred to in the study

ty

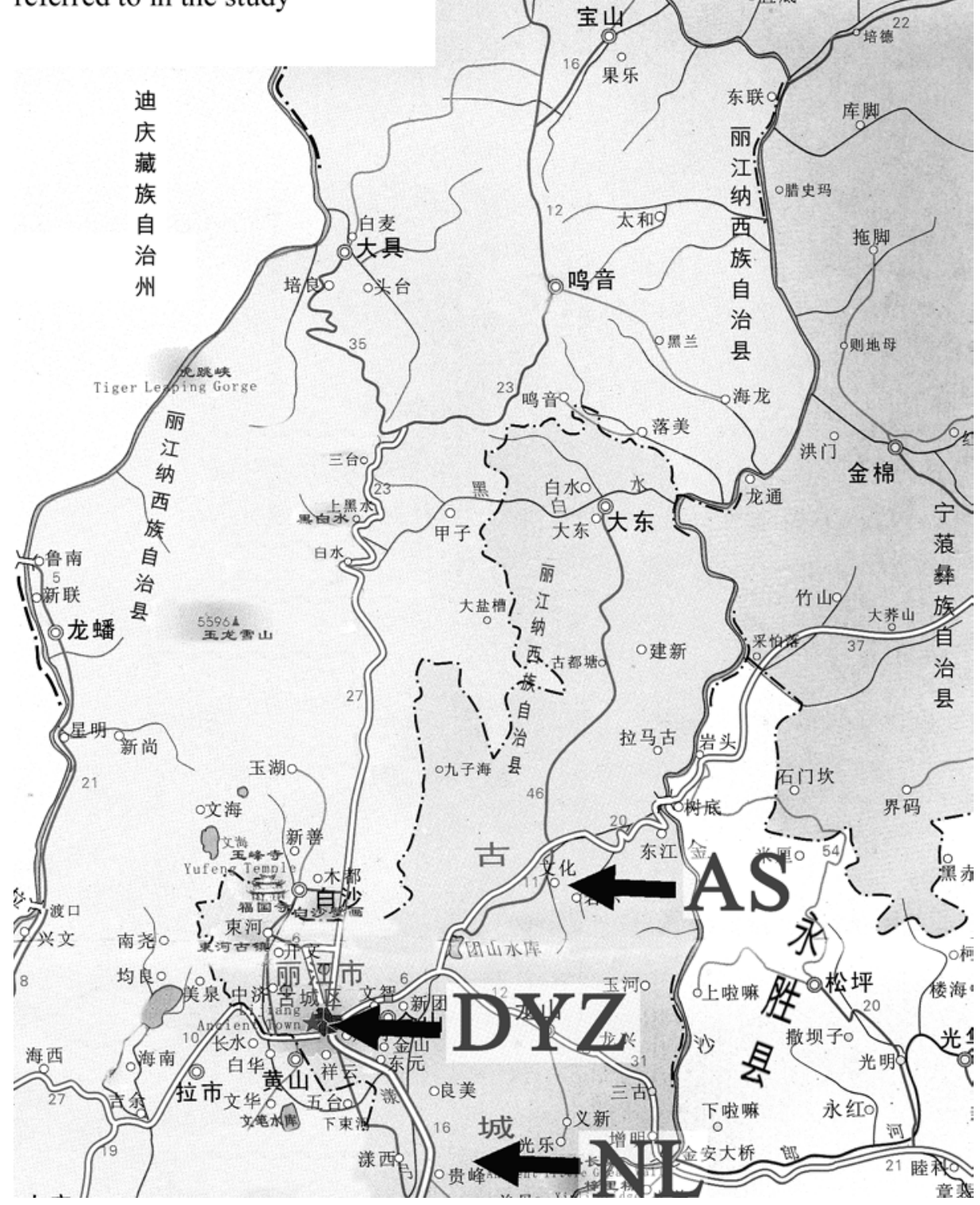


For the sake of convenience, second-hand data are rewritten to follow my own phonemic analysis in cases where first-hand familiarity with the dialect at issue shows that the same phonemic analysis applies. In particular, tones are rewritten as level tones, a choice which is partly based on the presence in Naxi of contourcreating floating tones reminiscent of those found in Subsaharian languages and elsewhere (as described by Odden 1995; Hyman 2001; Clements and Goldsmith 1984; the Naxi facts are set out in Michaud 2006).

1. The phonemicisation of the palatal initial /ç/ of the AS dialect by transphonologisation of a nasalisation contrast on vowels, still attested in the FK dialect

\subsection{Description and cross-dialect correspondences}

The FK dialect possesses three nasalised rhymes, / $\tilde{\mathrm{i}} /$, / $\tilde{y} /$ and / $\tilde{\mathrm{V}} /$. Phonemic analysis reveals that $/ \mathrm{h} /$ is the only phoneme which can appear before these rhymes; in this context, it is phonetically nasalised: its phonetic realisation can be approximated as [ $\left.\mathrm{h}^{\tilde{}}\right]$ before / $\tilde{i} /$ and / $\tilde{y} /$ (i.e. yielding [ $\tilde{h} \tilde{i}]$ and $[\tilde{h} \tilde{y}]$ ). In Naxi, the voiced fricative $/ \mathrm{v} /$ is a rhyme, and cannot appear as initial; before a nasal / $\tilde{\mathrm{y}}_{1} /$, an initial $/ \mathrm{h} /$ is realised as a nasal, labiodental, unvoiced sound, which can be approximated as [m]. Seven examples are provided in table 1, providing both a narrow phonetic transcription (in square brackets) and a phonemic analysis (between slashes). 


\begin{tabular}{|c|c|c|c|}
\hline $\mathrm{n}^{\circ}$ & FK & AS & meaning \\
\hline 1 & {$[\tilde{\mathrm{h}} \mathrm{y} \backslash] /$ hy } & [hy`]/ hy`' & red (红) \\
\hline 2 & [çju ']/hy / & {$[$ çу $] /$ çy $\%$} & tired (累) \\
\hline 3 & {$\left[\tilde{h}^{-1}\right] / h \tilde{r}^{-} /$} & {$\left[\mathrm{cis}^{-}\right] / \mathrm{hi}^{-} /$} & $\operatorname{man}$ (人) \\
\hline 4 & {$\left[\mathrm{çi}^{-}\right] / \mathrm{hi}^{-1}$} & {$\left[\mathrm{çi}^{-}\right] / \mathrm{hi}^{-/}$} & rice (paddy) (稻子) \\
\hline 5 & {$\left[\mathrm{~m} \tilde{\mathrm{v}}^{\prime}\right] / \mathrm{h} \tilde{v}^{\prime} /$} & {$[\mathrm{f} \overline{\mathrm{v}}] / / \mathrm{hv^{- }} /$} & hair (毛) \\
\hline 6 & [fỵ té] / hỵ té/ & {$\left[\mathrm{fe}^{\prime}\right] / \mathrm{hv}^{-} /$} & $\begin{array}{c}\text { tomb (坟墓) (Chinese } \\
\text { borrowing) }\end{array}$ \\
\hline 7 & [fṿ’] / hỵ`/ & {$[\mathrm{f} \overline{\mathrm{v}}]$ / hỵ̄/ } & $\begin{array}{l}\text { saw (锯) (probably a borrowing } \\
\text { from the Bai language) }\end{array}$ \\
\hline
\end{tabular}

Table 1. Narrow phonetic transcription of words exemplifying the nasal-vs.-oral contrast on vowels in the FK dialect, and corresponding words in the AS dialect. (As will be set out below, [y] and [ju] stand in a relation of allophony in FK.) To avoid confusion between tone diacritics and the diacritic for nasality, tones are marked to the right of the corresponding syllable.

The spectrograms in figure 1 illustrate the nasality contrast in the FK dialect, bringing out the difference between the realisations of $/ \mathrm{h} /$ when it precedes a nasal vowel (in which case the friction noise is weak), an oral, front high vowel (in which case it is realised as [ç]), or a voiced fricative $/ \mathrm{v} /$ (it is then realised as [f]). Recordings of items $1-5$ and 7 by a speaker of the FK dialect are available at http://ed268.univ-paris3.fr/lpp/pages/EQUIPE/michaud/NAXI/.

The correspondences which emerge are taken up in table 2.

\begin{tabular}{|l|c|c|c|c|c|c|}
\hline FK dialect & hỹ & hy & hĩ & hi & hỵ & hṿ \\
\hline AS dialect & hy & çy & çi & çi & hṿ & hṿ \\
\hline
\end{tabular}

Table 2. Phonemic correspondence between the dialects of FK and AS for six initial-rhyme combinations.

The [ju] sequence in the FK dialect can be analysed as an allophone of $/ \mathrm{y} /$. In $\mathrm{FK}, / \mathrm{y} /$ is realised as [ju] in the following contexts: in 

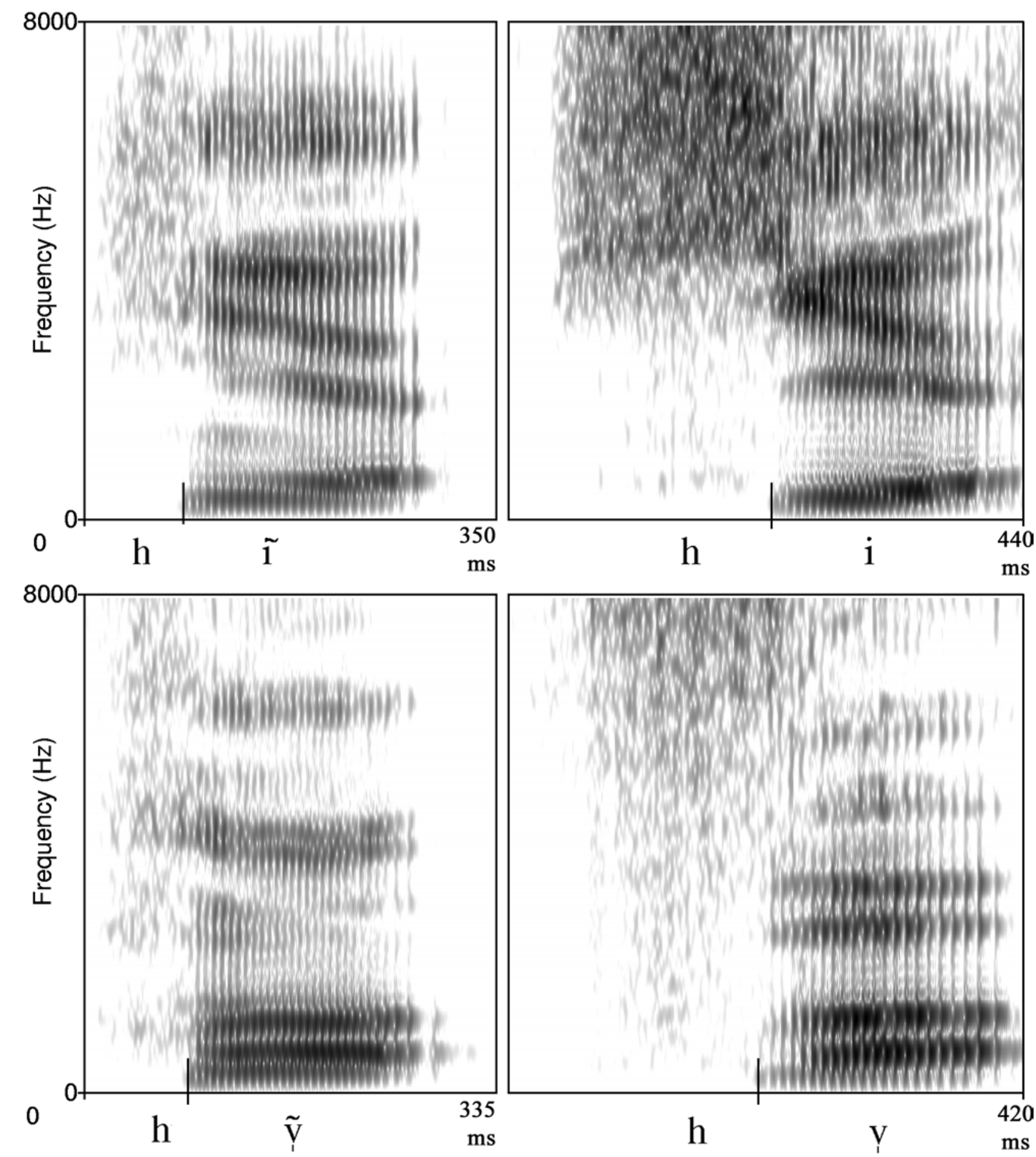

Fig. 1. Nasality contrasts in the FK dialect. Top: syllable / hĩ / (left), and / hi /, realised [çi] (right). Bottom: /hỵ / (left), and / hỵ/, realised [fy] (right). 
word-initial position, after the fricative $/ \mathrm{h} /$ (as in the word 'light (not heavy)': [jù], phonemically a simple /ỳ/), and after the velar $/ \mathrm{k} /$ (which it palatalises to [tç]). It is realised as [y] after coronals $/ \mathrm{nd} /$, $/ \mathrm{d} /, / \mathrm{t} /, \mathrm{t} \mathrm{h} /, / \mathrm{l} /$ and $/ \mathrm{s} /$, and bilabials $/ \mathrm{mb} /, / \mathrm{b} /, / \mathrm{p} /, / \mathrm{p} \mathrm{h} /$.

In $\mathrm{FK}$, [ç] is simply an allophone of $/ \mathrm{h} /$, which has a broad range of allophones, as it adopts some of the phonetic features of the rhyme that follows it: it is realised as nasalised $\left[\mathrm{h}^{\sim}\right]$ before nasal rhymes / $\tilde{\mathrm{i}} /$ and / $\tilde{\mathrm{y}} /$; as labiodental [m] and [f] before / $\tilde{\mathrm{y}} /$ and / $\mathrm{y} /$, respectively; as velar $[\mathrm{x}]$ before back vowels $/ \mathrm{w} /, / \mathrm{u} /, / \mathrm{y} /, / \mathrm{a} /$; as palatal [c] before close front oral $/ \mathrm{i} /$ and $/ \mathrm{y} /$; and as $[\mathrm{h}]$ before $/ \mathrm{x} /$, le/, /o/, /a/. ${ }^{1}$

In $\mathrm{AS}$, on the other hand, $/ \mathrm{ç} /$ and $/ \mathrm{h} / \mathrm{stand}$ in a relation of phonemic opposition before $/ y /$, and only before this vowel.

From a phonemic point of view, pairs 1-2 and 3-4 in table 1 appear to be distinguished by their rhyme in FK; words 1 and 2 appear to be distinguished by their initial in AS. Words 3 and 4 are homophonous in AS, as are also 5 and 7.

An alternative analysis would consist in transcribing the syllables

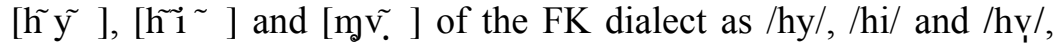
contrasting with /cy/, /ci/ and /fṿ/. However, this somewhat contrived analysis would not account for the presence of nasality.

It appears advisable, in the analysis of such out-of-the-way synchronic data, to look for a diachronic rationale, rather than draw out typological implications on the slender basis of the data at issue, as advised by Larry Hyman: "A complex nasal state may best be understood in terms of the nasal process which gives rise to it" (Hyman 1975:254; a similar viewpoint is expressed by Martinet

${ }^{1}$ The phoneme $/ \mathrm{h} /$ is distinct from the absence of any initial ['zero initial']; the phonetic realisation of syllables without an initial consonant is set out in another paper in the present volume, "Syllabic inventory of a Western Naxi dialect, and correspondence with Joseph F. Rock's transcriptions". 
[1955, 1975], and indeed underpins the approach of various other researchers). The diachronic evolution of the lexical contrasts at issue can be imagined as follows:

(1) at a first stage (a reconstructed, common earlier state), the oppositions were the following: /hỹ : hy/, /hĩ : hi/, and /hṽ : hỵ/; it can be imagined that, at that stage, the phonetic realisations were relatively straightforward (e.g. [hỹ] for /hỹ/, [hy] for /hy/);

(2) at a second stage, contextual allophonic variation in the initial consonant became strong: for instance, /hỹ/ was realised as

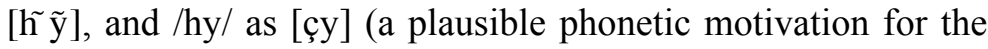
change from $[\mathrm{h}]$ to [c] before an oral, close, front vowel is outlined below). This is in fact how things stand at present in the FK dialect, where /hĩ /, realised as [hٓ̃ ], stands in contrast to /hi/, realised as [çi] (and /hỹ /, realised as [h̃̃y], stands in contrast to $/ \mathrm{hy} /$, which is realised, following the diphthongisation of $/ y /$ in this context, as [çju]);

(3) at a later stage, in AS (and other Western dialects), the contrast between nasal vowels and oral vowels was lost. In the case of former /hỹ/ and /hy/, the phonetic difference between initial [h] and initial [c] became phonemicised, so that the opposition was transphonologised as a contrast of initials: /hy/:/çy/. (Here and below, the colon : is used for relations of phonemic contrast.) In the case of former /hĩ / : /hi/, the opposition was lost without compensation in AS. There is at present no means to ascertain whether this loss was preceded by a stage in which the contrast was borne by the initial (i.e. /hi/ : /çi/).

Table 3 sums up this view of things. 


\begin{tabular}{|c|c|c|c|}
\hline & \multicolumn{3}{|c|}{ Phonetic realisation of the syllables } \\
\hline stage & Syll. with nucleus / y / & Syll. with nucleus / i / & Syll. with nucleus / y / \\
\hline $\begin{array}{l}\text { (1) reconstructed, } \\
\text { common earlier state }\end{array}$ & hỹ : hy & hĩ : hi & hr̃ $:$ hỵ \\
\hline $\begin{array}{c}\text { stage (2): allophonic } \\
\text { variation of the initial; } \\
\text { the contrast can still be } \\
\text { described } \\
\text { phonemically as a } \\
\text { contrast in vowels }\end{array}$ & $\tilde{h} \tilde{y}:$ çy & $\begin{array}{c}\text { h̃ } \tilde{i}: \text { çi } \\
\text { (in dialects other than } \\
\text { FK, the contrast may } \\
\text { have been lost before this } \\
\text { stage) }\end{array}$ & 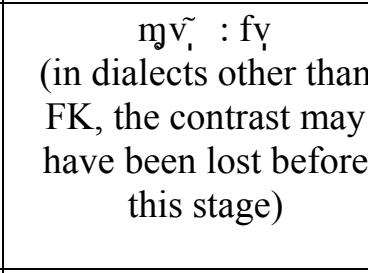 \\
\hline (3) present state & $\begin{array}{c}\text { in FK: hỹ : çju, by } \\
\text { diphthongisation of } / y / ; \\
\text { in AS: hy : çy, by loss } \\
\text { of nasality }\end{array}$ & $\begin{array}{l}\text { in FK: no change; in AS: } \\
\text { confusion to çi }\end{array}$ & $\begin{array}{l}\text { in FK: no change; in } \\
\text { AS: confusion to fy } \\
\text { (phonemically: } / \mathrm{hv} / \text { ) }\end{array}$ \\
\hline
\end{tabular}

Table 3. Hypotheses concerning the evolution of syllables with close front vowels after a glottal fricative in two dialects of Naxi, $F K$ and AS. (Unless placed between slashes, the notations are phonetic, not phonemic.)

Concerning the mechanisms of change, it is likely that the absence of palatalisation of initial $/ \mathrm{h} /$ when followed by a nasal vowel is due to the spread of nasalisation over the entire syllable (as a prosody in the Firthian sense). In the early stages of the evolution at issue, velum lowering presumably took place some time before the beginning of the vowel, by anticipation. An open velo-pharyngeal port is not easily compatible with the realisation of an oral fricative (be it [c] or another fricative such as [s]), insofar as fricatives require a relatively high air pressure behind the constriction, which does not easily obtain if the air can escape through the nose. In case there is a strong oral constriction (as is necessary for [c]]), the increased impedance of the oral tract will result in higher nasal airflow, while intra-oral pressure remains relatively low.

As for the reason why the lexical contrasts borne by /i/-vowel syllables are lost without compensation in the AS dialect, whereas 
they survive (by means of contrasts among initials) in /y/-vowel syllables, no simple articulatory or acoustic argument can be adduced; there does not appear to be any obvious phonetic motivation for this fact.

The evolution that took place in the AS dialect gives phonemic status to the sound [ç], in one single context: before vowel $/ y /$. The strict application of principles of synchronic description leads to the conclusion that these are extreme cases of neutralisation of phonemic contrasts: in AS, the contrast between /ç/ and $/ \mathrm{h} /$ is neutralised in all contexts save one (before $/ y /$ ); in FK, the contrast between nasal and oral vowels is neutralised in all positions except after $/ \mathrm{h} /$ (and, to preview section 2, the retroflex-vs.-dental contrast among certain consonants is neutralised in all positions except before $/ 0 /$ ).

It may appear unusual, and indeed counter-intuitive, to speak of neutralisation in these cases: it is more usual to use this notion to describe cases where a thoroughgoing contrast disappears in a restricted environment, e.g. in French, /e/ and / / / contrast only in open syllables, the opposition being neutralised in closed syllables. ${ }^{1}$ However, the term neutralisation should not be understood in a dynamic sense (whereby the opposition would have existed and then have been neutralised): it has a static - flatly synchronicapplication (Martinet 1969:257-259). It is not unusual for a synchronic formulation to be the reverse image of a diachronic

\footnotetext{
1 "Im Französischen kommen aber $e$ und $\varepsilon$ nur im offenen Auslaute als Glieder einer phonologisch-distinktiven Opposition vor (les-lait, allez-allait); in den übrigen Stellungen ist das Vorkommen von $e$ und $\varepsilon$ mechanisch geregelt (in gedeckter Silbe $\varepsilon$, in ungedeckter $e$ ), so daß diese zwei Vokale nur im offenen Auslaut as zwei Phoneme, in den übrigen Stellungen dagegen als kombinatorische Varianten eines einzigen Phonems gewertet werden müssen. Der phonologische Gegensatz ist also im Französischen in gewissen Stellungen a u f g e ho be n. Solche Oppositionen nennen wir a $\mathrm{u} f \mathrm{~h}$ e $\mathrm{b}$ b a r; jene Lautstellungen, in denen die Aufhebung erfolgt, A u fhebungsstellungen, jene, wo die Opposition relevant ist, R e l e v a n z s t e 11 u n g e n" (Trubetzkoy 1939:70).
} 
perspective: for instance, describing the synchronic stage when Chinese had three tones (A, B and C) contrasting on open/sonorantfinal syllables, it can be said that the tonal opposition was neutralised on the syllables of category D (obstruent-final syllables), although this opposition had never existed on these syllables. A diachronic perspective is therefore a useful complement to synchronic description; it helps preclude unwarranted typological conclusions. ${ }^{1}$

In addition to the above observations, let us mention that the correspondence between FK /hy/ and AS /çy/ is not verified in all cases. Table 4 provides examples of the following correspondence: FK /hy/, AS /su/. This correspondence is apparently due to a systematic confusion of the earlier */su/ and */hy/ to /hy/ in the FK dialect.

1 Larry Hyman reports a spectacular example illustrating the necessity to supplement synchronic description by diachronic reflection: in Wukari (Shimizu 1971), there exist syllables [ba], [bã], [mã], [mba], but neither [ma] nor [mbã]. (In this description, [b] stands for any of the following oral stops: $p, t, k$ or b, d, g, and [m] for a nasal, $\mathrm{m}, \mathrm{n}$ or $\mathrm{\eta}$.) Synchronically, nothing prevents the analysis of [mba] as the realisation of a simple $/ \mathrm{m} /+/ \mathrm{a} /$ sequence, [mã] being straightforwardly analysed as $/ \mathrm{ma} /$. This solution is economical in terms of the number of phonemic units used in the description, but at the cost of allophonic variation rules that contravene well-established typological regularities, and are apt to mislead typologists. A diachronic investigation actually reveals that mb already existed as a phoneme in its own right in earlier states of the language (Proto-Jukunoid), in which there were nine possible syllabic structures involving initial nasals or stops: *mam, *mab, *ma, *mbam, *mbab, *mba, *bab, *bam, *ba. Later, four phenomena took place: prenasalised stops became geminate nasals in cases where the syllable had a final nasal; these geminate nasals simplified to simple nasals; vowels became nasalised when preceded or followed by a nasal consonant; lastly, final consonants fell (Hyman 1975:262). 


\begin{tabular}{|c|c|c|c|}
\hline FK & AS & English translation & $\begin{array}{c}\text { Chinese } \\
\text { translation }\end{array}$ \\
\hline hỳ & sù & $\begin{array}{c}\text { iron; homophone: } \\
\text { clean }\end{array}$ & 铁 \\
\hline hý $\mathrm{k}^{\mathrm{h}}$ wà & sú $\mathrm{k}^{\mathrm{h}}$ wò & ugly & 丑 \\
\hline hý hȳ & $\begin{array}{c}\text { sù, which } \\
\text { reduplicates to suu sù }\end{array}$ & to look for & 寻找 \\
\hline
\end{tabular}

Table 4. Illustration of the correspondence between AS/su/and FK /hy/, in phonemic notation

Let us note in passing that a change from [su] to [ç] or the other way round is also attested in the domain of Chinese dialects. To take an example, the word for 'tuber', 薯 (pinyin shǔ), the phonemes of which are / $/ \mathrm{gu} /$ in Standard Chinese, is $/ 6 y^{5} /$ in the Gan (赣) dialect of Nanchang (nán chāng 南昌), probably a borrowing from the Mandarin dialect of Hankou (hànkǒu 汉口), a more conservative dialect in this respect (Sagart 1993:121). (As an anecdote, let us also mention that the Chinese name 徐, pronounced [cy] in Mandarin, is sometimes anglicised as [Ju:].)

\subsection{Preliminary diachronic hypotheses as to the origin of nasal vowels}

The above reflections suggest that the state of affairs observed in the FK dialect is somewhat more conservative than that observed in AS. In turn, this raises the issue of how nasal vowels came about in Naxi.

Across languages, the development of nasal vowels under the influence of nasal consonants in coda position (the final consonants then disappearing) is common, e.g. from Latin to Modern French, and in some Chinese dialects that have lost final nasals, such as Qingdao (qīng dăo 青岛); phonetically, it is well established that lowering of the velum for a final nasal consonant begins before oral 
closure, nasalising the vowel (to a degree which varies across languages, speaking rates and speaking styles; see, e.g., Cohn 1990 and references therein).

There is no evidence that Naxi had final nasals at any stage of its history, however. 'Red', item 1 of tables 1 and 2 above, is hóng (红) in standard Mandarin Chinese, with a final nasal, but this is a mere coincidence: the meaning of this word changed from 'rose' to 'red' in the course of its history (as pointed out to us by William Baxter); moreover, the genetic relationship between Chinese and Naxi is so distant that the quest for surface similarities does not make sense.

Interestingly, languages related to Naxi have initial nasals in some words whose cognates have nasal vowels in FK Naxi. 'Body hair', /hv' '/ in FK Naxi, is reconstructed as *mul by Benedict 1972, as *?mwe3 by Bradley 1979. 'Red', /hy Y/ in FK, is reconstructed by Benedict as *r-ni, by Bradley as *?nil. 'Man, human being', is reconstructed by Benedict as *r-miy; it might be that the form /hĩ ${ }^{-/}$ observed in FK Naxi is derived from *r-miy, whereas the nasalplus-/i/ syllables observed in present-day Naxi (e.g. in / $\mathrm{mi}^{\prime} /$ 'woman', $/ \mathrm{mi}^{-} /$'fire') come from other sources, such as unprefixed nasals. These tentative comparisons suggest that the nasal vowels of Naxi could originate in former nasal initials.

Across languages, there are several processes whereby an initial nasal consonant may become de-nasalised. It may evolve into a prenasalised stop, then lose prenasalisation $(\mathrm{m}>\mathrm{mb}>\mathrm{b}$, $\mathrm{n}>\mathrm{nd}>\mathrm{d}, \mathrm{y}>\mathrm{ng}>\mathrm{g}$ ), as in some Chinese dialects (Chen 1975) and in the Southern Loloish languages Bisu and Phunoi. This evolution bears indirect testimony to the cross-language tendency for nasalisation to spread beyond the initial consonant: in a language that contrasts, e.g., /ma/ and $/ \mathrm{ma} /$, the evolution of $/ \mathrm{ma} /$ towards $/ \mathrm{mba}$ / may be a means to block the propagation of nasality from $/ \mathrm{m} /$ onto the following syllable, a propagation which would threaten the opposition between /ma/ and /mã/ (Larry Hyman 
describes this as "perceptual reinforcement of the orality of a neighboring vowel": Hyman 1975:256, 259). In Naxi, there were arguably no nasal vowels prior to the process investigated here; analogues to the situation in Naxi are therefore to be sought elsewhere.

Nasalisation of a vowel by a preceding nasal consonant is well attested in the Yi-Burmese languages: closed vowels (typically /i/ or $/ \mathrm{u} /$ ) are frequently nasalised after a nasal consonant, as in Arakanese, a dialect of Burmese (Bradley 1985); indeed, in some languages they disappear altogether (Bradley 1989). Data from the Nosu and Phunoi languages lead David Bradley to reconstruct a historical change from a devoiced nasal consonant $/ \mathrm{g} /$ to $/ \mathrm{h} /$, by loss of the oral closure, followed by the loss of nasality (Bradley 1979); the latter change is highly plausible from a phonetic point of view, since the acoustic effect of velum lowering becomes minimal in the absence of an oral closure (see also the discussions in Ohala 1975).

In Tamang (Martine Mazaudon, personal communication), the combination of an initial $/ \mathrm{y} /$ and an oral vowel freely alternates with an initial $/ \mathrm{h} /$ followed by a nasal vowel: for instance, 'to call' is sometimes realised as [ ${ }^{4}$ not-pa], sometimes as [ ${ }^{4}$ hõt-pa] (the superscript figure at the beginning of the word indicates lexical tone).

To conclude, it can be imagined that the nasal vowels of FK Naxi originate in the lenition of a nasal initial (or an initial consonant cluster) and its change to $/ \mathrm{h} /$ (probably through an intermediate stage in which $/ \mathrm{h} /$ had become a voiceless nasal). This raises an issue in terms of historical depth of the process; in the perspective outlined here, in order to account both for present-day nasal-initial syllables (of the structure $/ \mathrm{mi} /$ ) and for present-day nasal vowels (as in /hĩ /), it is necessary to posit initial consonant clusters; there is in fact no evidence that such clusters were present at the stage when nasal vowels appeared. Lastly, at present one cannot rule out the 
possibility that the Naxi facts are a case of rhino-glottophilia as described by Matisoff 1975 (nasalisation of vowels in the environment of $/ \mathrm{h} /$ or $/ \mathrm{l} /$ ), in which case the contrast between $/ \mathrm{hi} /$ and /çi/ observed in AS would represent a stage preceding phonetic evolution towards [hĩ] vs. [çi] and subsequent phonemic reinterpretation as /hĩ / vs. /hi/.

\subsection{Supplementary data for the study of nasalisation in Naxi}

In the AS dialect, initial $/ \mathrm{y} /$ only combines with three rhymes: $/ \mathrm{y} /$, /a/ and /v/. It could be that, at earlier stages, /y/-initial syllables were more numerous, a conjecture which is supported by data from the FK dialect, in which $/ \mathrm{n} /$ combines with $/ \mathrm{u} /$ and $/ \mathrm{wa} /$, as illustrated by the examples in table 5 .

\begin{tabular}{|c|c|c|c|}
\hline FK & $\mathrm{AS}$ & English translation & $\begin{array}{l}\text { Chinese } \\
\text { translation }\end{array}$ \\
\hline $\begin{array}{l}\text { jwa (in: sá } \\
\text { jwà- }{ }^{-}, \quad \text { jwà } \\
\text { mē, ndā } \text { jwā) }\end{array}$ & $\begin{array}{l}\text { wa (in: sá } \\
\text { wā, wá mē, } \\
\text { ndā wā) }\end{array}$ & $\begin{array}{l}3^{\text {rd }} \text { month, } 5^{\text {th }} \\
\text { month, } 12^{\text {th }} \text { month }\end{array}$ & $\begin{array}{l}\text { 三月, 五月, } \\
\text { 十二月 }\end{array}$ \\
\hline ywà $^{-}$ & $w \bar{a}$ & $\begin{array}{l}\text { tile [probably a } \\
\text { Chinese borrowing] }\end{array}$ & 瓦 \\
\hline jù & wà & copula & 是 \\
\hline yù ${ }^{-}$ & kō & to water & 浇(浇菜) \\
\hline$\eta \overline{\mathrm{u}}$ & $\begin{array}{lll}\eta \bar{\gamma} & \text { (in: } \quad \eta \bar{\gamma} \\
g \bar{\gamma}) & \\
\end{array}$ & $\begin{array}{l}1^{\text {st }} \text { sg., in possessive } \\
\text { constructions }\end{array}$ & 我(的) \\
\hline yà & ฤyे & $1^{\text {st }} \mathrm{sg}$. & 我 \\
\hline ฤप̣̀ & n⿳亠े & $\begin{array}{l}\text { silver; homophone } \\
\text { to cry }\end{array}$ & 银; 哭 \\
\hline
\end{tabular}

Table 5. Correspondences between the dialects of FK and AS for syllables with an initial velar nasal.

It can reasonably be hypothesised that the conservative form is that with an initial nasal. These facts recall the evolution of the $1^{\text {st }}$ 
person singular (wǒ 我) of standard Mandarin: it is thought to originate in $* /$ naj $2 /$, a form which is postulated for the period between 1300 B.C. and 250 B.C. (late Shang to Western Zhou); wú 吾, likewise a $1^{\text {st }}$ person pronoun, originates in an older $* / \mathrm{ya} /$ (Sagart 1999:142-146; see also Sagart 1993:123-124). The $1^{\text {st }}$ person pronoun (我) retains an initial velar nasal in many presentday Southwest Mandarin dialects (Yang Shih-Feng 1984:1718).

One question which remains unanswered is why only three nasal vowels, $/ \tilde{1} /, / \tilde{y} /$ and $/ \tilde{y} /$, are now extant in FK Naxi. That out-ofthe-way patterns should be observed on closed vowels is relatively common (in Mon, for instance, they also present unexpected correspondences [Christian Bauer, personal communication]); concerning nasalisation, Hajek and Maeda, supplementing the observations of Chen 1975 and Matisoff 1975:272, show that low vowels do not necessarily have a stronger propensity to nasalisation: "...there appear to be two competing universal tendencies, if not universals : one is of preferential nasalization of high vowels, and the other is of preferential nasalization of vowels with greatest duration (generally accepted to be low vowels)" (Hajek and Maeda 2000:68). Further investigation into this question will necessitate a systematic investigation into the Naxi cognates of the nasal-initial syllables of other Yi-Burmese languages.

2. Contrasts of retroflexion on coronal initials in the AS dialect are restricted to a single context: before the vowel /o/

\subsection{Description}

In the dialects of FK and AS, retroflex stops [ $\eta \mathrm{d}],[\mathrm{d}],[\mathrm{t}],\left[\mathrm{t}^{\mathrm{h}}\right]$, nasal $[\eta]$ and lateral [ $l]$ stand in a relationship of allophonic variation to nonretroflex [nd], [d], [t], [th], [n] and [1], the former appearing before rhymes $/ \mathfrak{x} /, / \mathrm{u} /$, and $/ \mathrm{u} /$, the latter before all other vowels. (By the strength of its release, the $/ l /$ is close to the sound 
described as $[\mathrm{r}]$ in the International Phonetic Alphabet.) For instance, 'to close (a door)' is [t’']; there is no such phonetic product as [trí] in the Naxi dialects of AS and FK. Nonetheless, in a manner reminiscent of the contrast between $/ \mathrm{h} /$ and $/ \mathrm{cc} /$ in the AS dialect, there is one single context in which the AS dialect of Naxi presents a contrast of retroflexion on coronal initials (stops, nasals and laterals): before the vowel /o/. Said differently, the opposition of retroflexion is neutralised before all vowels save $/ \mathrm{o} /$. To take the example of syllables with an unvoiced stop $/ \mathrm{t} /$ or $/ \mathrm{t} /$, the attested combinations are the following:

\begin{tabular}{|c|c|c|c|c|c|c|c|c|c|c|c|}
\hline & $\mathrm{i}$ & $\mathrm{y}$ & ш & $\mathrm{u}$ & e & $\gamma$ & 0 & $\mathrm{a}$ & $a$ & $\bar{x}$ & $\bar{c}$ \\
\hline $\mathrm{t}$ & \multirow[t]{2}{*}{$\mathrm{ti}$} & \multirow[t]{2}{*}{ ty } & \multirow[b]{2}{*}{ tu } & & \multirow[t]{2}{*}{ te } & & to & \multirow[t]{2}{*}{ ta } & \multirow[t]{2}{*}{ ta } & \multirow[b]{2}{*}{ tar } & \multirow[t]{2}{*}{ tỵ } \\
\hline $\mathrm{t}$ & & & & & & & to & & & & \\
\hline
\end{tabular}

i.e. the distribution of / $\mathrm{t} /$ and / $\mathrm{t} /$ is almost complementary, but not quite.

Table 6 presents lexical oppositions (checked with four language consultants). The examples for $/ \mathrm{t} /$ and $/ \mathrm{t}^{\mathrm{h}} /$ do not appear to be basic, reliable words, but the examples for $/ \mathrm{nd}: \mathrm{nd} /, / \mathrm{n}: \eta /, / 1: 1 /$ appear convincing. 


\begin{tabular}{|c|c|c|c|}
\hline initial & tone & dental consonant $+/ \mathrm{o} /$ & retroflex consonant $+/ \mathrm{o} /$ \\
\hline \multirow[t]{3}{*}{$n: \eta$} & $\mathrm{L}$ & $\begin{array}{l}\text { /nò/ 'merchandise, object that can be } \\
\text { sold at the market (typically: produce } \\
\text { of the farm)' (商品) }\end{array}$ & $\begin{array}{l}\text { /nò/ 'moth' (蛙虫); 'strand (of thread)' } \\
\text { (量词) 根 (一根线) }\end{array}$ \\
\hline & M & $\begin{array}{l}\text { /nō/ 'fodder, grasses that pigs and } \\
\text { cows can eat' }\end{array}$ & $\begin{array}{l}\text { /nō/ 'milk' (奶); ‘to smell’ (闻); } \\
\text { 'family name' (姓) }\end{array}$ \\
\hline & $\mathrm{H}$ & $\begin{array}{l}\text { /nó/ (borrowing) 'glutinous (e.g. } \\
\text { glutinous rice)' 糯 (糯米); 'to take, to } \\
\text { seize' }\end{array}$ & 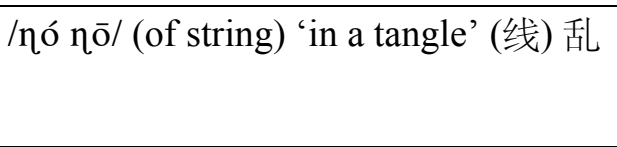 \\
\hline \multirow[t]{3}{*}{$1: l$} & $\mathrm{~L}$ & $\begin{array}{l}\text { /lo/ 'inside'; 'muntjac deer, Muntiacus } \\
\text { reevesi' (鹿子); 'valley'; 'to take } \\
\text { charge of, assume responsibility for' }\end{array}$ & /ū lò/ 'yoke' (轭) (/ū̄/ : ‘cow') \\
\hline & $\mathrm{M}$ & $\begin{array}{l}/ \text { /lō/ 'work' (/lō bē/ 'to work'; /bē/ } \\
\text { 'do'); /tō lō/ 'straw hat' (斗笠); /á lō/ } \\
\text { 'grandfather, forebear' }\end{array}$ & 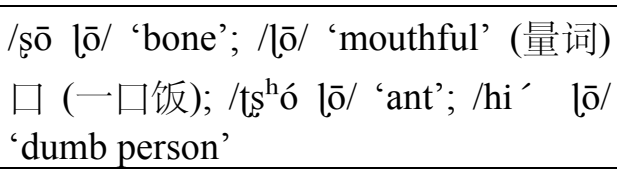 \\
\hline & $\mathrm{H}$ & $\begin{array}{l}\text { /ló/ 'to stride over, to cross' (跨: } \\
\text { 跨小沟); /ló lē bū//'to go back' (/lē/ } \\
\text { 'again', /būi / 'go') }\end{array}$ & /ló pi / ‘chilli peppers’ (辣椒) \\
\hline \multirow[t]{3}{*}{$t^{\mathrm{h}}: \mathrm{t}^{\mathrm{h}}$} & $\mathrm{L}$ & $\begin{array}{l}/ \mathrm{t}^{\mathrm{h}} \mathrm{\textrm {O }} / \text { 'to sit against, to be propped } \\
\text { against' (靠) }\end{array}$ & / thò ' 'to sleep like a log' (睡得很深) \\
\hline & $\mathrm{M}$ & /thōo/ 'pine' (松树); 'rabbit' & $\begin{array}{l}\text { / } \mathrm{t}^{\mathrm{h}} \overline{\mathrm{O}} / \text { 'to slap gently' (轻轻地敲), e.g. } \\
\text { slapping a child }\end{array}$ \\
\hline & $\mathrm{H}$ & /thó/ ‘insert, inlay’ (镶进去) & $\begin{array}{l}\text { /thó/ (onomatopoeia) sound of a small } \\
\text { object (e.g. a small stone) that falls to } \\
\text { the ground. The tone varies across } \\
\text { informants: it is either high or mid. }\end{array}$ \\
\hline \multirow[t]{3}{*}{$t: t$} & $\mathrm{~L}$ & /tò/ 'to obey' & $\begin{array}{l}\text { /tò/ (onomatopoeia) sound of a branch } \\
\text { that is snapped }\end{array}$ \\
\hline & $\mathrm{M}$ & $\begin{array}{l}\text { /tō/ 'board (of wood)'; /tō lō/ 'straw } \\
\text { hat' (斗笠) }\end{array}$ & 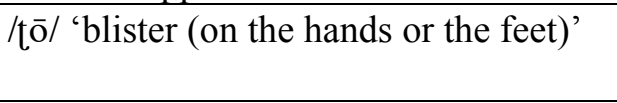 \\
\hline & $\mathrm{H}$ & /tó/ 'forehead' & /tó lō/ 'to wind up, to roll up' (卷起来) \\
\hline
\end{tabular}




\begin{tabular}{|c|c|c|c|}
\hline $\mathrm{d}$ & L-M- & \multicolumn{2}{|c|}{ no oppositions; the only combination observed is [do], e.g. [do] 'see' (看见). } \\
\hline \multirow[t]{3}{*}{$\begin{array}{l}\text { nd } \\
\eta \mathrm{d}\end{array}$} & $\mathrm{L}$ & /ndò/ 'stupid' (愚蚌) & $\begin{array}{l}\text { /ndo/ 'reel, spool (of thread)' (量词) } \\
\text { 团 (一团线); /nd̄o ndò çỹ çỳl } \\
\text { 'hurriedly' (急急忙忙) }\end{array}$ \\
\hline & $\mathrm{M}$ & /ndō/ 'to climb’ (爬) & $\begin{array}{l}\text { /nd̄/ ' to sting (a wasp stings)'; 'to } \\
\text { knock (at a door)' }\end{array}$ \\
\hline & $\mathrm{H}$ & $\begin{array}{l}\text { /ndó/ 'to fall down' (跌倒); /ō ndó/ 'to } \\
\text { thresh (with a flail)' }\end{array}$ & $\begin{array}{l}\text { /ndó lō/ 'a bag, a load' } \\
(\text { 一小包, 一坨儿); /ndó/ 'to roll up } \\
\text { (thread, paper, plastic foil...) into a } \\
\text { ball'; (onomatopoeia) noise of a small } \\
\text { object that hits you, e.g. a nut falling } \\
\text { on your head }\end{array}$ \\
\hline
\end{tabular}

Table 6. Lexical words illustrating the retroflex-vs.-dental opposition among coronal consonants in the AS dialect of Naxi.

Phonetically, the realisation of the vowel is slightly affected by the initial consonant: [o] is more closed and more rounded after retroflex coronals than after dentals. It may be useful to point out that the contextual allophones of /o/ after coronal consonants do not impinge on the phonetic domain of neighbouring vowels: no confusion takes place between the syllables in table 6 and any of the syllables made up of a vowel $/ \mathrm{u} /, / \mathrm{u} /, / \mathrm{r} /$ preceded by a coronal consonant (which, before these vowels, is realised as retroflex). To take an example, the imperative form of the verb 'to come', realised as $[l \bar{u}]$, does not get confused with $/[\overline{\mathrm{o}} /$, 'yoke' (realised as $[l \bar{o}]$ ).

\subsection{Synchronic analysis: contrast on the initial, or on the rhyme?}

In synchrony, some arguments need to be adduced to support the view (implicit in the notations used in table 6) that the contrasts are borne by the initial, rather than by the rhyme. A university teacher who was born in the village of AS, He Xueguang (和学光教授), became aware of the lexical distinctions carried by the syllabic 
contrasts at issue; he added a rhyme - uo, distinct from $-\mathrm{o}$, to the romanised Naxi script (whose standard version is presented by $\mathrm{He}$ Jiren et al. 1985:130-134 and He Zhiwu 1987) which he occasionally teaches at the Naxi Culture Education Centre that he founded in Lijiang. Table 7 illustrates the equivalences between a phonetically-oriented transcription (that indicates both the differences on the initial and on the rhyme), He Xueguang's notation, and the phonemic analysis put forward here.

\begin{tabular}{|c|c|c|}
\hline $\begin{array}{l}\text { approximation } \\
\text { in IPA }\end{array}$ & $\begin{array}{ll}\text { romanised } & \text { notation } \\
\text { proposed by He Xueguang }\end{array}$ & phonemic analysis \\
\hline $10: 10$ & luo : lo & $10: 10$ \\
\hline ฤ : no & nuo : no & пo : no \\
\hline
\end{tabular}

Table 7. Approximation in IPA, romanised notation proposed by He Xueguang, and phonemic analysis of certain contrasts among syllables with and without retroflexion.

The analysis in terms of a difference on the rhyme is more economical in that it only requires the addition of one unit to the phonemic inventory (a vowel /o/). From the point of view of structural economy, however, the recognition of a fourth back rounded vowel amounts to adding a fourth degree of vocalic aperture to a vowel system which otherwise requires only three. This would moreover introduce an asymmetry between a three-way aperture contrast among front vowels $(/ \mathrm{i} /, / \mathrm{e} /, / \mathrm{a} /)$ and a four-way contrast among back vowels-phonetically an unusual configuration.

This argument is not decisive, however, as cross-linguistic tendencies should not be taken as rules to go by in the description of individual languages (as pointed out by Nolan 1999, and illustrated by vowel systems such as that of the Bora language, documented by Parker 2001, which opposes, among back vowels, $/ \mathrm{t} /, / \mathrm{w} / \mathrm{and} / \mathrm{o} /)$. 
Another argument comes from comparison with related languages: in Burmese, the presence of a contrast between semi-closed and semi-open vowels $(/ \mathrm{e} /$ and $/ \varepsilon /, / 0 /$ and $/ \rho /)$ is an innovation of Central Burmese; Arakanese and Marma dialects only distinguish three degrees of vowel aperture (Denise Bernot, personal communication). This argument is not decisive either, however: two otherwise close dialects can have widely different vocalic systems (witness the differences between regional varieties of French or English: differences in vowel inventories are larger than differences in consonants).

From a phonetic point of view, it seems to me that the difference on rhymes is much less salient than the difference on initials. I consider this a clinching argument in favour of the present phonemic analysis. To conclude, this is, again, a case of extreme neutralisation: the contrast between retroflex and dental coronal consonants is neutralised in all contexts save one-before /o/.

\subsection{Cross-dialect comparison}

Cross-dialect comparison indicates that the contrasts which are presently carried by retroflex- $v s$.-nonretroflex initials in AS probably go back a long way. Oppositions between retroflex and non-retroflex coronal initials are not found in DYZ (the variety of Naxi spoken in the town of Lijiang) or in the neighbouring dialects: there, 'milk' and 'fodder' are homophonous (/nō/), as are 'to climb' and 'to sting' (/ndō/), 'inside' and 'yoke' (/lò/). In some cases, however, the vowel of the words corresponding to the two forms in AS (with and without retroflexion) is different: thus, 'to sting (a wasp stings someone)', /nd $\overline{0} /$ in AS, is $/ \mathrm{nd} x /$ in the speech of a DYZ consultant, and $/ \mathrm{d} \overline{\mathrm{y}} /$ in the speech of a younger consultant (about 30 years old) who also lives in Lijiang, where both her parents always lived. (As was mentioned above, the coexistence of several dialectal varieties in Lijiang does not come as a surprise, given that it is the main city of the Naxi area.) 
In the NL dialect, one and the same vowel appears in all the words that correspond to words that comprise an /o/ after a non-retroflex in AS (left column of table 6): vowel /o/ (phonetically realised as $[ø])$. Various vowels correspond to the $/ 0 /$ vowels that follow retroflex initials in AS, however: mainly /a/, but also /o/ and $/ \mathrm{u} /$. Table 8 presents four such correspondences, which may hint at an earlier opposition, perhaps one of initials.

\begin{tabular}{|c|c|c|c|c|}
\hline initial & $\mathrm{AS}$ & $\mathrm{NL}$ & corresp. & English and Chinese translation \\
\hline \multirow[t]{2}{*}{$\eta$} & nò & nà & o VS. a & moth 蛙虫 \\
\hline & $\eta \bar{o}$ & nō & o VS. o & milk 奶 \\
\hline \multirow[t]{2}{*}{ nd } & ndò & ndù & o VS. u & $\begin{array}{l}\text { reel, spool (of thread) (量词) 团 } \\
\text { (一团线) }\end{array}$ \\
\hline & ndō & ndā & \multirow[t]{4}{*}{ o VS. a } & to sting (a bee stings) (蜜蜂)叮咬 \\
\hline \multirow[t]{3}{*}{$l$} & ló pi` & lā pi & & hot peppers 辣椒 \\
\hline & șō lō & șā lā & & bone 骨头 \\
\hline & ū lò & ū là & & yoke 轭子 \\
\hline
\end{tabular}

Table 8. Some examples of NL cognates of the retroflex-initial syllables of the AS dialect.

The opposition between retroflex and non-retroflex coronal consonants is lost in NL, the corresponding words being homophonous with other syllables: e.g. 'yoke' is /là/, homophonous with 'hand' (the latter word being /là/ in NL as well as in AS). Were it not for cross-dialectal evidence, no trace of the opposition could be found in NL.

Li Lincan et al. 1953 (whose language consultant was Hé Cái 和才, a native of Ludian [lŭ diàn 鲁甸]) distinguish between a [1] and a 
[r], with a distribution which corresponds to that of $/ 1 /$ and $/ l /$ in my own data, i.e. contrasting only before $/ \mathrm{o} /{ }^{1}$ They do not draw the phonemic implications of this state of affairs, but the evidence they offer suggests that the retroflex/nonretroflex oppositions in table 6 are attested in Ludian as well as in AS.

The data collected by Fu Maoji also show a similar set of phonemic oppositions (based on the speech of 和芳 Hé Fāng, born in the village of Zhonghe [zhōng hé 中和村]: see Fu Maoji 1981:8, 297307). According to linguists He Jiren 和即仁 and He Limin 和力民 (personal communication), this informant lived in several dialect areas, and was strongly influenced by the dialect of Yangxi (yàng xī 漾西). Discussions with He Jiren, himself born in Yangxi, showed that the opposition is present in his dialect.

So far, internal comparison does not shed light on the origin of this set of retroflex consonants. One wonders whether some medial elements were involved at one stage. Systematic comparison of Naxi with Burmese, Yi, and (Southern) Qiangic languages will be attempted in a later study to obtain further insights.

3. Syllables with medial lip-rounding $/ \mathrm{w} /:$ a $/ \mathrm{w} \gamma /$ rhyme, labialised initials, or a /w/ medial?

The AS dialect possesses syllables with lip-rounding $/ \mathrm{w} /$ followed by the rhotic vowel $/ x /$ Syllables made up of a coronal initial /nd/, $/ \mathrm{d} /, / \mathrm{t} /, / \mathrm{th} /, / \mathrm{ndz} /, / \mathrm{dz} /, / \mathrm{ts} /, / \mathrm{ts} \mathrm{h} /, / \mathrm{s} /$ or $/ \mathrm{z} /$ followed by vowel $/ \boldsymbol{x}^{\prime} /$ in the DYZ and NL dialects have two correspondences in AS, one of

\footnotetext{
${ }^{1}$ The correspondence between their data and mine is not entirely straightforward. All of the syllables which they transcribe as [lo] correspond to the /lo/ of my own data; some syllables that they transcribe as [ro], however, correspond to [lu] in my data, e.g. [rō] "four", [lū] in my data. The phrase they give for "Sichuan", [ró ph $\overline{\mathrm{a}}$ dỳ], could not be checked because the informants I consulted use a loanword to refer to this Chinese province.
} 
which possesses medial lip-rounding $/{ }^{\mathrm{w}} /$ between its initial consonant and its vowel. Thus DYZ/NL $/ \mathrm{s} \check{\gamma} /$ 'seven' is likewise $/ \mathrm{s} \bar{x} /$ in AS, whereas 'full (a container/vessel is full)', DYZ/NL / ${ }^{2}$ ' (Mazaudon et al. 1979:31, He Jiren et al. 1985:167), is $/ \mathrm{s}^{\mathrm{w}} z^{\prime} /$ in AS. Table 9 presents the oppositions that were observed in AS. 


\begin{tabular}{|c|c|c|}
\hline contrast & $\begin{array}{|lll|}\begin{array}{l}\text { syllable } \\
\text { rounding }\end{array} & \text { without } & \text { lip } \\
\end{array}$ & syllable with lip rounding \\
\hline \multirow[t]{3}{*}{$\begin{array}{l}\text { unvoiced } \\
\text { aspirated } \\
\text { stop }\end{array}$} & \multirow[t]{3}{*}{ (thor: not attested) } & $\begin{array}{l}/ \mathrm{t}^{\mathrm{W}} \partial^{\prime} \mathrm{th}^{\mathrm{W}} \bar{\gamma} / \text { 'to pack up' (reduplicated } \\
\text { form of } / \mathrm{t}^{\mathrm{W}} \gamma^{\prime} / \text {; the simplex form is not } \\
\text { in common use) }\end{array}$ \\
\hline & & $\left(t^{h^{W}} \overline{\partial^{2}}:\right.$ not attested $)$ \\
\hline & & 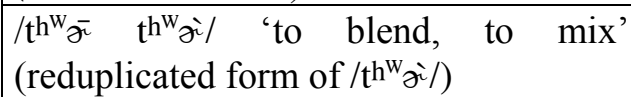 \\
\hline \multirow[t]{3}{*}{$\begin{array}{l}\text { unvoiced } \\
\text { stop }\end{array}$} & $/$ trí $^{\prime}$ 'to close (a door...)' & $\begin{array}{l}/ \mathrm{t}^{\mathrm{w}} \partial^{\prime} / \text { 'to do wickerwork, to make a } \\
\text { basket' (/mú t } \mathrm{t}^{\mathrm{w}} \mathfrak{x}^{\prime} / \text { 'to do bamboo } \\
\text { wickerwork' }\end{array}$ \\
\hline & (toi: not attested) & $/ \mathrm{t}^{\mathrm{w}} \approx /{ }^{2} /$ 'to tie' (拴) \\
\hline & /tうi 'ghost' (魔鬼) & $/ \mathrm{t}^{\mathrm{W}}$ ว̀/ 'cutting-board' (菜板) \\
\hline \multirow[t]{3}{*}{ voiced stop } & \multirow[t]{3}{*}{ (dr: not attested) } & $/ \mathrm{d}^{\mathrm{w}} \mathfrak{x}^{\prime} /:$ proper noun (for a person) \\
\hline & & $/ \mathrm{d}^{\mathrm{w}} \bar{x} /$ 'shelf, shelves' (架子) \\
\hline & & $/ \mathrm{d}^{\mathrm{w}} \partial$ '/ 'bubble; to simmer/boil' \\
\hline \multirow[t]{3}{*}{$\begin{array}{l}\text { prenasalised } \\
\text { stop }\end{array}$} & (ndó: not attested) & $\begin{array}{l}\text { /nd } \mathrm{n}^{\mathrm{w}} \mathrm{\gamma}^{\prime} / \text { (onomatopoeia) sound of gong, } \\
\text { cymbals }\end{array}$ \\
\hline & $\begin{array}{|lr|}\operatorname{lnd} \bar{x} /: \text { modality verb 'be } \\
\text { necessary, r must'; } \\
\text { interchangeable with }\left[\bar{l}^{\bar{c}}\right] \\
\end{array}$ & $\begin{array}{l}\text { /nd }{ }^{\mathrm{w}} \bar{\gamma} / \text { 'pond'; 'fake' (in: } / \mathrm{nd}^{\mathrm{w}} \bar{\gamma} \mathrm{ni}^{\prime} / \text {, } \\
\text { 'fake') }\end{array}$ \\
\hline & $\begin{array}{l}\text { /ndふi/ 'to call out loud, to } \\
\text { cry out' }\end{array}$ & (nd a: not attested) \\
\hline $\begin{array}{l}\text { unvoiced } \\
\text { aspirated } \\
\text { retr. affr. }\end{array}$ & $/ \mathrm{tse}^{\mathrm{h}} \bar{x} /$ 'to wash' & 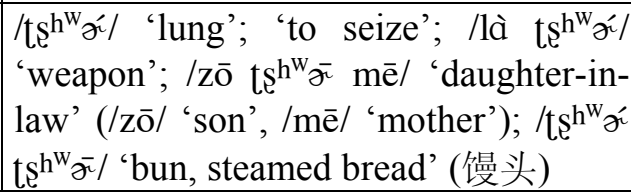 \\
\hline $\begin{array}{l}\text { unvoiced } \\
\text { retrofl. affr. }\end{array}$ & 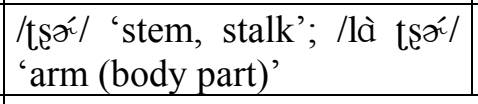 & 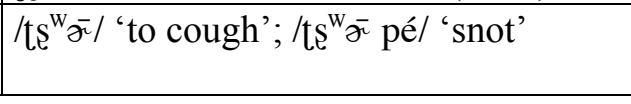 \\
\hline $\begin{array}{l}\text { voiced retr. } \\
\text { affr. }\end{array}$ & \multicolumn{2}{|c|}{$\left(d z \partial^{2}, d z^{W}:\right.$ not attested $)$} \\
\hline prenasalised & (ndzor: not attested) & $/ \mathrm{ndz}_{\mathrm{z}}{ }^{\mathrm{x}} \overline{\mathrm{r}}$ ' to swim'; 'moist', also in \\
\hline
\end{tabular}




\begin{tabular}{|c|c|c|}
\hline retr. affr. & & 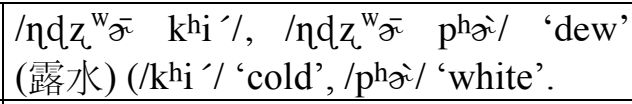 \\
\hline $\begin{array}{ll}\text { voiced fric. } \\
\text { retr. }\end{array}$ & $\begin{array}{l}\left|z_{\imath} \bar{r}\right| \text { 'to be afraid of'; /zว̀): } \\
\text { onomatopoeia }\end{array}$ & $/ \mathrm{z}^{\mathrm{W}} \bar{\partial} \overline{\mathrm{r}}$ thē/ 'knife'; variant: /zū thē/ \\
\hline $\begin{array}{l}\text { unvoiced } \\
\text { fric. retr. }\end{array}$ & $\begin{array}{l}\text { /s } \bar{x} / \text { 'seven'; 'thing'; / } \mathrm{s}^{\prime} \text { / } \\
\text { 'headscarf' (头帕) }\end{array}$ & $\begin{array}{l}/ \mathrm{S}^{\mathrm{w}} x^{\prime} / \text { '(to fill/full) to the brim'; 'light } \\
\text { meal' }\end{array}$ \\
\hline $\begin{array}{l}\text { lateral } \\
\text { approx. }\end{array}$ & \multicolumn{2}{|c|}{ no opposition; attested syllable: [ $\left.\mathfrak{l}^{\sim}\right]$} \\
\hline
\end{tabular}

Table 9. Lexical words illustrating the oppositions between syllables with and without lip-rounding after a coronal initial in the AS dialect.

The authors who describe Naxi dialects that possess medial labialisation before $/ \mathrm{r} /$ adopt various solutions for its transcription. In his modified version of Naxi romanisation, He Xueguang (a native of the AS dialect, as mentioned above) transcribes the lip rounding found on these items by using a $-v r$ rhyme, e.g. shvr for the combination that I transcribe as $/ \mathrm{s}^{\mathrm{w}} \mathrm{r} /$ (in Naxi romanisation, $s h$ stands for $/ \mathrm{s} /$ ). His own pronunciation of the rhyme is especially closed and retroflex; it could be transcribed as [ $\left.{ }^{\mathrm{W}} \mathrm{I}\right]$, adding that both articulations are simultaneous: the rhyme is slightly rounded throughout.

Li Lincan et al. 1953 record a [ur] rhyme, which contrasts with the $\left[{ }^{r}\right]$ rhyme (which they transcribe as $[\Lambda \mathrm{r}]$ ). (Recall that the variety of Naxi they study is that of Ludian, lǔ diàn 鲁甸.) The distribution of this rhyme, both rhotic and rounded, by and large corresponds with that of $/ \mathrm{w} r /$ in AS. Pending further investigation into the Ludian dialect, it is not yet possible to indicate whether it is phonetically closer to $[\mathrm{u}]$ or to the $\left[{ }^{\mathrm{w}} \mathrm{\gamma}\right]$ observed in AS.

Fu Maoji 1984:304 reports a [lù̀.s] syllable, illustrated by the words 'to meet up, to get together' (聚集) and 'disorderly, topsy-turvy' (慌乱), though his data do not include a [li... counterpart which 
would testify to the existence of an actual opposition in terms of lip rounding. Judging from the notation system used by this author, the syllable nucleus would be $/ \Lambda \mathrm{s} /$, which can be interpreted, by comparison with my own data, as $/ \mathrm{r} /$. The semi-vowels $/ \mathrm{w} /$ and $/ \mathrm{j} /$ are all written $/ \mathrm{u} /$ and $/ \mathrm{i} /$ by $\mathrm{Fu}$ Maoji (a practice which is in fact common among Chinese linguists).

As mentioned above, Fu Maoji's language consultant, He Fang (和芳), comes from Zhonghe (zhōng hé 中和) but probably adopted pronunciation traits of the dialect of Yangxi (yàng xi 漾西), the speech of his wife and in-laws. In the speech of the linguist $\mathrm{He}$ Jiren, himself a native speaker of the Yangxi variety of Naxi, the opposition of lip rounding is present, and its phonetic realisation corresponds to what has been observed in the AS dialect. Having become accustomed to the standard notation proposed for Western Naxi (in IPA, and with equivalents in romanised script), He Jiren does not indicate lip rounding in his own transcriptions.

As in section 3 above, the issue arises as to whether the difference lies in the initial or the rhyme, or whether medial semi-vowels should be acknowledged in the syllabic structure of Naxi. This recalls the general issue of "The non-uniqueness of phonemic solutions of phonetic systems" raised by Chao Yuen-ren 1934. The notations of $\mathrm{Fu}$ Maoji 1984 and Li Lincan et al. 1953 amount to attributing the contrast to the rhyme. The cross-dialect correspondences that have so far been brought to light do not appear to provide any particular arguments in favour of one of the competing analyses. It appears that, in the FK dialect, lip rounding was lost without compensation in some cases (e.g. 'dew' is $/ \eta \mathrm{dz}_{\mathrm{z}}{ }^{\mathrm{w}} \overline{\mathrm{r}}$

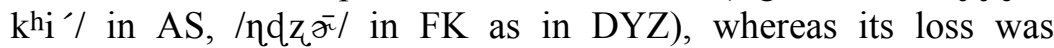
accompanied by a change in the rhyme - and in the tone - in other cases (the change in rhyme and tone may admittedly be due to quite a different cause, however). Table 10 presents three correspondences of the AS syllables at issue with syllables with rhyme / $\mathrm{y} /$ or /wa/ in FK. 


\begin{tabular}{|c|c|c|c|c|}
\hline initial & $\overline{\mathrm{AS}}$ & FK & corresp. & $\begin{array}{l}\text { English and Chinese } \\
\text { translation }\end{array}$ \\
\hline Z & $\mathrm{z}^{\mathrm{w}} \bar{\partial}^{\mathrm{n}} \mathrm{ndzà}$ & z Ýr ndz & $\mathrm{w}_{\partial \bar{r}} V S . \dot{\gamma}$ & willow 柳树 \\
\hline nd & gi ${ }^{\prime} d^{\mathrm{W}} \bar{\partial}$ & ndwá & ${ }^{\mathrm{w}} \bar{\partial} \boldsymbol{r} V S$. wá & pond 池塘 \\
\hline \multirow[t]{2}{*}{$n d z$} & $\eta d_{z}{ }^{w} \bar{r}$ & $n d z x^{\prime}$ & $\mathrm{w}_{\bar{x}} \overline{x^{\prime}} . \partial^{\prime}$ & wet 湿 \\
\hline & $\eta d_{z}{ }^{w} \bar{r}^{-}$ & ndz $a^{-}$ & $\mathrm{w}_{\bar{\gamma}} V S . \partial^{\bar{\gamma}}$ & dew 露水 \\
\hline
\end{tabular}

Table 10. Illustration of the correspondences between syllables with medial labialisation of the $A S$ dialect and cognates in the FK dialect.

Phonetically, in the syllables with medial labialisation, the initial and the vowel $/ 2 /$ are somewhat rounded phonetically, but both are still clearly recognisable. The synchronic solution chosen here consists in acknowledging the existence of $/ \mathrm{w} /$ as a medial semivowel, thus considering that the syllabic structure of Western Naxi is $(\mathrm{C})(\mathrm{G}) \mathrm{V}$, where $\mathrm{C}$ stands for a consonant, $\mathrm{G}$ (Glide) for a semivowel $/ \mathrm{w} /$ or $/ \mathrm{j} /$, and $\mathrm{V}$ a vowel, the only indispensable component of the syllable. The distribution of medial semi-vowels is severely limited: both appear only before /a/, /a/, / $/$ and / $/$ /, and only after certain consonants. This analysis diminishes the vocalic inventory by eight units: /wa/, /wa/, /wr/, /wo/ (which is phonetically realised as [və] when occurring on its own), /ja/, /ja/, /jy/, and /jo $/$.

\section{Concluding remarks}

The present analyses, which illustrate the 'tightly structured nature of the syllable in monosyllabic languages' (Matisoff 1973) and echo the general reflections of Eugenie Henderson on "Feature shuffling in Southeast Asian languages" (Henderson 1985), aimed to contribute to a better synchronic understanding of the three phonemic issues that were discussed. From a diachronic point of view, these case studies in Naxi phonemics hopefully offer some stepping-stones towards a goal which is still distant: to reach a clearer view of the position of Naxi within Sino-Tibetan, and in 
particular its position vis-à-vis languages of the Burmese-Yi subgroup ('Burmese-Lolo'), which to date remains somewhat uncertain (Bradley 1975, 1979, 1997:37; see also the preliminary remarks by Okrand 1974, and Nishida 1985).

\section{Acknowledgments}

Many thanks to David Bradley, Martine Mazaudon, Jacqueline Vaissière and the two reviewers of this paper for detailed comments and suggestions, and to Christian Bauer, William Baxter, Michel Ferlus, Boyd Michailovsky and Laurent Sagart for very useful comments and discussions. My thanks to the Naxi informants, colleagues and friends, especially Guo Dalie (郭大烈教授), $\mathrm{He}$ Jiren (和即仁先生), He Jiezhen (和洁珍女士), He Xueguang (和学光教授), He Xuan (和漩), He Qin (和沁), He Yong (和涌), He Xixian (和希贤), Mu Ruhua (木汝华), and their families, and to Laura Bennetts and Liberty Lidz for useful exchanges about Eastern Naxi. I alone am responsible for remaining shortcomings.

\section{References}

BENEDICT Paul K. (1972). Sino-Tibetan: A Conspectus. Cambridge: Cambridge University Press.

BRADLEY David (1975). Nahsi and Proto-Burmese-Lolo. Linguistics of the Tibeto-Burman Area, 2, no 1, pp. 93-150.

BRADLEY David (1979). Proto-Loloish. London \& Malmö: Curzon Press.

BRADLEY David (1985). Arakanese vowels. In: THURGOOD Graham, MATISOFF James A. and BRADLEY David (eds). Linguistics of the Sino-Tibetan area: The state of the art. Canberra: Pacific Linguistics C-87. Pp. 180-200. 
BRADLEY David (1989). Nasality as a prosody in Loloish. In: BRADLEY David, HENDERSON Eugénie J.A. and MAZAUDON Martine (eds). Prosodic Analysis and Asian Linguistics: to honour R.K. Sprigg. Canberra: Pacific Linguistics C-104. Pp. 143-155.

BRADLEY David (1995). Grammaticalisation of extent in MranNi. Linguistics of the Tibeto-Burman Area, 18, no 1, pp. 128.

BRADLEY David (1997). Tibeto-Burman languages and classification. In: BRADLEY David (ed). Papers in Southeast Asian linguistics No.14: Tibeto-Burman languages of the Himalayas. Canberra: Department of Linguistics, Research School of Pacific and Asian Studies, Australian National University. Pp. 1-64.

CHAO Yuen-ren 赵元任 (1934). The non-uniqueness of phonemic solutions of phonetic systems. Bulletin of the Institute of History and Philology, Academia Sinica, 4, no 4, pp. 363397.

CHEN Matthew Y. (1975). An areal study of nasalization in Chinese. In: FERGUSON Charles A., HYMAN Larry M. and OHALA John (eds). Nasálfest: Papers from a Symposium on Nasals and Nasalization. Stanford: Stanford University. Pp. 81-124.

CLEMENTS Nick and GOLDSMITH John (1984). Autosegmental Studies in Bantu Tone. Dordrecht (Holland)/ Cinnaminson (USA): Foris Publications.

COHN Abigail C. (1990). Phonetic and Phonological Rules of Nasalization. Los Angeles, UCLA Working Papers in Linguistics 76.

FU Maoji 傅禁勣 (vol. 1: 1981, vol. 2: 1984). Naxi-zu tuhua-wenzi “Bai bianfu qu jing ji” yanjiu 纳西语图画文字 《白蝙蝠取经记》研究 [A study of the Naxi pictographic 
manuscript "White Bat's Search for Sacred Books"], Computational Analyses of Asian and African Languages (Tokyo), Monograph Series 6.

HAJEK John and MAEDA Shinji (2000). Investigating Universals of Sound Change: the Effect of Vowel Height and Duration on the Development of Distinctive Nasalization. In: BROE Michael and PIERREHUMBERT Janet (eds). Papers in Laboratory Phonology V. Cambridge: Cambridge University Press. Pp. 52-69.

HE Jiren 和即仁 and JIANG Zhuyi 姜竹仪 (1985). Naxiyu jianzhi 纳西语简志 [A Brief Monography on the Naxi Language]. Beijing: Minzu Chubanshe 民族出版社 (Zhongguo shaoshu minzu yuyan jianzhi congshu 中国少数民族语言简志丛书).

HE Zhiwu 和志武 (1987). Naxiyu Jichu Yufa 纳西语基础语法 [A Basic Grammar of Naxi]. Kunming: Yunnan Minzu Chubanshe 云南民族出版社.

HENDERSON Eugénie J.A. (1985). Feature shuffling in Southeast Asian languages. In: RATANAKUL Suriya, THOMAS David and SUWILAI Premsrirat (eds). Southeast Asian Linguistic Studies presented to André-G. Haudricourt. Bangkok: Mahidol University. Pp. 1-22.

HYMAN Larry M. (1975). Nasal states and nasal processes. In: FERGUSON Charles A., HYMAN Larry M. and OHALA John (eds). Nasálfest: Papers from a Symposium on Nasals and Nasalization. Stanford: Stanford University. Pp. 249264.

HYMAN Larry M. (2001). Tone systems. In: HASPELMATH Martin, KÖNIG Ekkehard, OESTERREICHER Wulf and RAIBLE Wolfgang (eds). Language typology and language universals: An international handbook, vol. 2. Berlin \& New York: Walter de Gruyter. Pp. 1367-1380. 
LI Lincan 李霖灿, ZHANG Kun 张琨, HE Cai 和才 (1953). Moxie xiangxing wenzi zidian 麼些象形文字字典 [A dictionary of Moxie pictographs]. Hong Kong: Shuowenshe 说文社. Revised edition in 2001 by Yunnan Minzu Chubanshe 云南民族出版社, under the title Naxi xiangxing wenzi zidian 纳西象形文字字典 [A dictionary of Naxi pictographs], with some changes - and typos - in the phonetic transcriptions.

MARTINET André (1955). Economie des changements phonétiques. Bern, Switzerland: A. Francke AG Verlag.

MARTINET André, ed. (1969). La linguistique: guide alphabétique. Paris: Denoël.

MARTINET André (1975). Evolution des langues et reconstruction. Paris: Presses Universitaires de France.

MATISOFF James A. (1973). Tonogenesis in Southeast Asia. In: HYMAN Larry M. (ed). Consonant Types and Tones. Southern California Occasional Papers in Linguistics 1. Pp. 71-96.

MATISOFF James A. (1975). Rhinoglottophilia: the mysterious connection between nasality and glottality. In: FERGUSON Charles A., HYMAN Larry M. and OHALA John (eds). Nasálfest: Papers from a Symposium on Nasals and Nasalization. Stanford: Stanford University. Pp. 265-87.

MATISOFF James A. (2003). Handbook of Proto-Tibeto-Burman: system and philosophy of Sino-Tibetan reconstruction. Berkeley \& Los Angeles: University of California Press.

MAZAUDON Martine and MICHAILOVSKY Boyd (1979). Naxi [Nahi]-English vocabulary. Unpublished manuscript.

MICHAUD Alexis (2006). Tonal reassociation and rising tonal contours in Naxi. Linguistics of the Tibeto-Burman Area, 29, no 1.

NISHIDA Tatsuo (1985). The Hsihsia, Lolo, and Moso languages. In: THURGOOD Graham, MATISOFF James A. and 
BRADLEY David (eds). Linguistics of the Sino-Tibetan Area: the state of the art. Papers presented to Paul K. Benedict for his 71 st birthday. Canberra, Australia: A.N.U.

NOLAN Francis (1999). The devil is in the detail. Proceedings of the $14^{\text {th }}$ International Congress of the Phonetic Sciences, San Francisco, pp. 1-8.

ODDEN David (1995). Tone: African languages. In: GOLDSMITH John (ed). Handbook of Phonological Theory. Oxford: Blackwell. Pp. 444-475.

OHALA John (1975). Phonetic explanations for nasal sound patterns. In: FERGUSON Charles A., HYMAN Larry M. and OHALA John (eds). Nasálfest: Papers from a symposium on nasals and nasalization. Language Universals Project. Stanford. Pp. 289-316.

OKRAND Marc (1974). Na-khi and Proto-Lolo-Burmese: A Preliminary Survey. Linguistics of the Tibeto-Burman Area, 1, no 1, pp. 55-97.

PARKER Steve (2001). The acoustic qualities of Bora vowels. Phonetica, 58, pp. 179-195.

PINSON Thomas M. (1998). Naxi-Chinese-English Glossary, with English and Chinese Indexes. Dallas: Summer Institute of Linguistics.

SAGART Laurent (1993). Les dialectes gan. Etudes sur la phonologie et le lexique d'un groupe de dialectes chinois. Paris: Langages croisés.

SAGART Laurent (1999). The Roots of Old Chinese. Amsterdam: John Benjamins.

SHIMIZU Kiyoshi (1971). Comparative Jukunoid: an introductory survey. Ph. D., University of Ibadan, Nigeria.

THURGOOD Graham (2003). A subgrouping of the Sino-Tibetan languages: The interaction between language contact, change, and inheritance. In: THURGOOD Graham and 
LAPOLLA Randy (eds). The Sino-Tibetan languages. London: Routledge. Pp. 3-21.

TRUBETZKOY Nikolaus S. (1939 [1976]). Grundzüge der Phonologie [Principles of Phonology]. Prague: Travaux du cercle linguistique de Prague 7. Reprinted 1968 by Kraus Reprint, Nendeln/Liechtenstein. 